\title{
The influence of goal-directed fluid therapy on the prognosis of elderly patients with hypertension and gastric cancer surgery
}

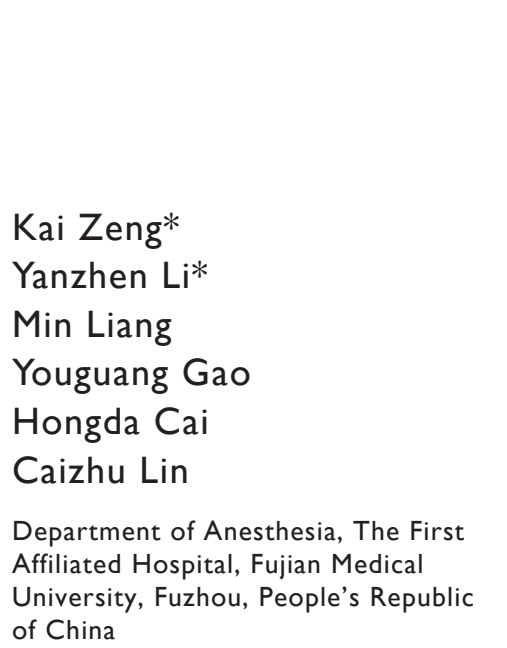

*These authors contributed equally to this work
This article was published in the following Dove Press journal: Drug Design, Development and Therapy 29 October 2014

Number of times this article has been viewed

Purpose: We aimed to investigate the influenc (GDFT) on the prognosis of elderly patients y

Methods: Sixty elderly patients $(>60 \mathrm{y} s$ old $)$ wh primary spertension who received gastric cancer radical surgery and wh American of Anesthesiologists (ASA) class II or III were enrolled in the curent stus. Selected parents were divided randomly into two arms, comprising a conventi_intraoperat Guid management arm ( $\operatorname{arm~C,~n=30)}$ and a GDFT arm (arm G, n=30). P ents in arm $\mathrm{C}$ were indsed with crystalloids or colloids according to the methods of Mille Anesthesia hedition), while those in arm G were infused with $200 \mathrm{~mL}$ hydroxyethyl starc ver $15 \mathrm{~min}$ ss under the FloTrac/Vigileo monitoring system, with stroke volup variation b reen 80 and 13\%. Hemodynamics and tissue perfusion laboratory indicators paw recorded continuously from 30 minutes before the operation to 24 hours after th oper

Resul mpared arm $\mathrm{C}$, the average intraoperative intravenous infusion quantity in arp o was gnifican reduced $(2,732 \pm 488 \mathrm{~mL}$ versus $3,135 \pm 346 \mathrm{~mL}, P<0.05)$, whereas rage co significantly increased $(1,235 \pm 360 \mathrm{~mL}$ versus $760 \pm 280 \mathrm{~mL}$, $P<$ In addition, there were more patients exhibiting intraoperatively and postoperatively stable h odynamics and less patients with low blood pressure in arm G. Postoperative complications re less frequent, and the time of postoperative hospital stay shorter, in arm G. No nificant differences were observed in mortality between the two arms.

Co Iusion: Our research showed that GDFT stabilized perioperative hemodynamics and reduced the occurrence of postoperative complications in elderly patients who underwent gastric cancer surgery.

Keywords: stroke volume variation, gastric cancer, the elderly

\section{Introduction}

Fluid therapy is an integral part of daily anesthesia, as well as one of the most debated issues in perioperative management. With the aging of the population, more and more patients are in need of large-scale noncardiac surgery. ${ }^{1-3}$ Elderly hypertensive patients with hypovolemia and hypoxia are often unable to tolerate such surgery due to postoperative complications. The traditional methods normally introduce more liquid, but easily lead to tissue edema and postoperative low blood pressure. These methods also slow tissue healing and increase the incidence of complications such as pulmonary infection. Furthermore, rapid rehydration loading within a short time can easily lead to acute pulmonary edema and heart failure, which is often life threatening. ${ }^{4-7}$ Therefore, more stringent standards are required for fluid administration in elderly patients, and anesthetists should operate with great cautiousness. Since there are no
Correspondence: Caizhu Lin Department of Anesthesia, The First Affiliated Hospital, Fujian Medical University, No. 20 Chazhong Road, Fuzhou 350005, People's Republic of China

Tel/Fax +86 59l 87981987

Email lincaizhu2013@yeah.net 
instruments that can accurately assess blood volume or tissue perfusion, or accurately predict liquid overload, most studies $^{8-11}$ have focused on the selection of types of blood for the perioperative treatment. Clinically, the decision regarding the amount of liquid to use during the surgery still depends on the anesthesiologist's experience and patient's tolerance.

Stroke volume variation (SVV) is an accurate and easy parameter by which to measure fluid responsiveness and functional hemodynamic parameters. It can be used to guide fluid therapy in mechanically ventilated patients. In the present study, we aimed to investigate the effect of goal-directed fluid therapy (GDFT) on prognosis in elderly hypertensive patients receiving gastric cancer surgery. The purpose is to provide a more objective basis for intraoperative fluid therapy and further refine the technique to improve outcomes for elderly patients.

\section{Materials and methods}

\section{Patient selection}

This study was approved by the ethics committee of Fujian Medical University, Fuzhou, People's Republic of China. All patients signed consent forms. Between March 2011 and December 2012, 60 elderly hypertensive patients (old than 60 years) undergoing abdominal cancer surgery wer enrolled in the study. All patients had normal p rative blood pressures. According to the standards 9 am ican Society of Anesthesiologists (ASA), the pro erati tions of patients were classed as gradec or III. averaged body mass index (BMI) was $<30$, $\mathrm{v}^{2}$, and the reraged preoperative hematocrit level was $>0.3$, L. Patients were excluded if they had seco ary hypertens severe cardiopulmonary diseases coronary heart disease, congenital heart disease, pneumo to reulosis, pulmonary malignant tumors, eto kidney sfunctions, or clear arrhythmia. de diag ostic c a for hypertension were based on inese 10 masion Prevention Guide, 2010. ${ }^{12}$ All patients ro ed regular preoperative antihypertensive treatments. Using andom selection, patients were divided into two arms: a conventional infusion arm ( $\operatorname{arm} C, n=30)$ and a GDFT group (arm G, n=30).

\section{Perioperative management}

\section{Preparation before anesthesia}

All patients received a restricted diet preoperatively. After entering the operation room, local anesthesia was administered by left radial artery catheterization guided by Doppler ultrasound (SKK24-S6 xk 9/1; Zhongxi Yuanda Technology Co., Ltd., Beijing, People's Republic of China). Using a multifunction monitor (Datex-Ohmeda $\mathrm{S} / 5^{\mathrm{TM}}$ type), heart rate (HR), systolic blood pressure (SBP), diastolic blood pressure (DBP), mean arterial pressure (MAP), central venous pressure (CVP), oxygen saturation $\left(\mathrm{SpO}_{2}\right)$, end-tidal carbon dioxide partial pressure $\left(\mathrm{PETCO}_{2}\right)$, and other indicators were continuously monitored. The FloTrac/Vigileo system (version 1.10; Edwards Lifesciences, Irvine, CA, USA) was used to obtain cardiac output/cardiac index (CI), stroke volume (SV)/stroke index, SVV, and other hemodynamic parameters.

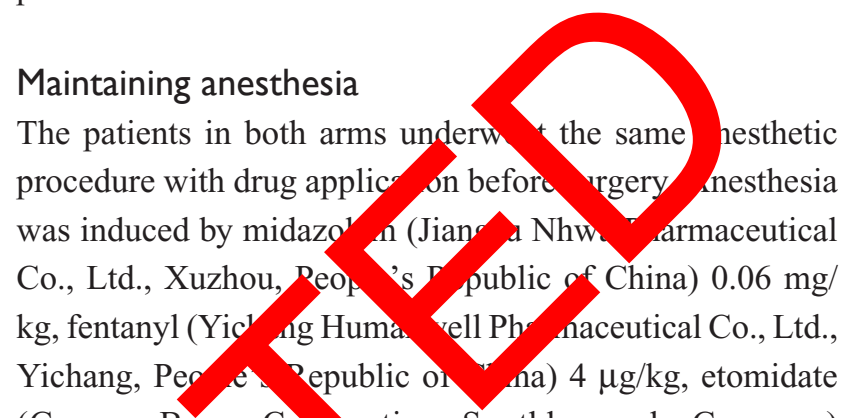
(German Braun Co, ration, Southborough, Germany) $0.3 \mathrm{~m}$, is-atracuriù GlaxoSmithKline plc, London, UK $0.2 \mathrm{mg} / \mathrm{kg}$, followed by intravenous injection. Intubation was ompleted th ugh video-assisted laryngoscopy. After intub. n, a D? $x$-Ohmeda 7,100 ventilator was used to ontrol broumng during anesthesia. All patients were suppl a $8 \mathrm{~mL} / \mathrm{kg}$ tidal volume mechanical ventilation to naintain a respiratory ratio (times of inhale:times of exhale) f $1: 2$ and respiratory rate of 10 to 14 breaths per minute, ensure a $\mathrm{PETCO}_{2}$ level of $\sim 35-45 \mathrm{mmHg}$. The airway pressure was kept at less than $25 \mathrm{~cm} \mathrm{H}_{2} \mathrm{O}$. The anesthesia was maintained with inhalation of $1.5 \%$ to $3 \%$ sevoflurane (Jiangsu Nhwa Pharmaceutical Co., Ltd.), in air mixed with $50 \% \mathrm{O}_{2}$. Intermittent boluses of cis-atracurium $0.04 \mathrm{mg} / \mathrm{kg}$ and fentanyl $1 \mu \mathrm{g} / \mathrm{kg}$ were administered. A bispectral index of between 40 and 60 was also maintained.

\section{Volume management}

The FloTrac/Vigileo device was used to measure SVV and other hemodynamic parameters. Patients in arm $\mathrm{C}$ underwent conventional fluid therapy management according to the methods of Miller's Anesthesia (6th edition). ${ }^{13}$ The management objective for arm $\mathrm{G}$ was to induce $200 \mathrm{~mL}$ of $6 \%$ hydroxyethyl starch within 15 minutes each time, with SVV between $8 \%$ and $13 \%$, under the monitoring of the FloTrac/Vigileo system. When the measured SVV was 13\% above the normal level (lasting for 5 minutes), or the current subtest reaction was positive (SV increased more than $10 \%$ ), an additional $200 \mathrm{~mL}$ of Voluven ${ }^{\circledR}$ was introduced. Intraoperatively, insulation blankets and a continuous heating device were used to maintain patient temperatures at 
above $36^{\circ} \mathrm{C}$. Blood transfusion was conducted if bleeding constituted more than one-quarter of the total blood volume. Finally, all patients were treated postoperatively by the same team of physicians.

\section{Monitoring indicators}

\section{Basic indicators}

Patients were scheduled preoperative visits and vital information was collected, which included sex, age, weight, height, blood pressure classification, ASA classification, BMI, hemoglobin levels $(\mathrm{Hb})$, preoperative complication type, etc.

\section{Hemodynamics}

All patients were continuously monitored in terms of conventional hemodynamic parameters, including HR, SBP, DBP, MAP, CVP, $\mathrm{SpO}_{2}$, and other indicators. The FloTrac/ Vigileo system was used to obtain cardiac output/CI, SV/ stroke index, SVV, and other hemodynamic parameters. Hemodynamic indexes of MAP, HR, and CVP were recorded at the following time points: 30 minutes before surgery $\left(\mathrm{T}_{0}\right)$; at the beginning of surgery $\left(\mathrm{T}_{1}\right) ; 1$ hour after the initial surgery $\left(\mathrm{T}_{2}\right)$; at the onset of surgery $\left(\mathrm{T}_{3}\right) ; 6$ hours after surgery $\left(\mathrm{T}_{4}\right) ; 12$ hours after surgery $\left(\mathrm{T}_{5}\right)$; and 24 hours after surgery $\left(\mathrm{T}_{6}\right)$. Also, the perioperative hypotensive events, as SBP $<90 \mathrm{mmHg}$, DBP $<50 \mathrm{mmHg}$, or a $>30 \%$ in blood pressure compared with baseline were recorded. Once hypotensive events curred phedri was administrated to accelerate the in sion r s recorded patients' undergoing stal hu nes, colloids, blood losses, and urine outpu

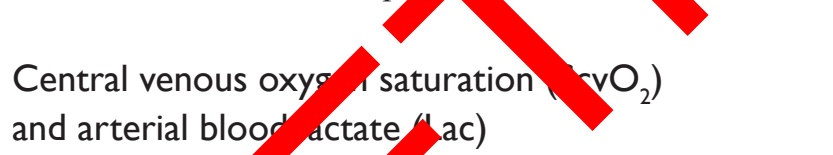
Blood samples wer olle a from the jugular vein and radial artery in all ants a $\mathrm{T}_{1}, \mathrm{~T}, \mathrm{r}_{3}, \mathrm{~T}_{4}, \mathrm{~T}_{5}$, and $\mathrm{T}_{6} . \mathrm{ScvO}_{2}$ and Lac cre the measu, a blood gas analyzer.

Postoper econditions

The postope ive exhaust times were recorded. If any of postoperative nousea and vomiting, low blood pressure, cardiac arrhythmia, oliguria, anastomotic fistula, or other complications occurred multiple times, patients were immediately transferred to the intensive care unit. Postoperative complications were observed by physicians who were blinded to the two arms in combination with patient self-reports.

\section{Statistical analysis}

Data were analyzed by SPSS 18.0 software. Normal distribution was assessed with mean \pm standard deviation. Within arms, data were assessed by using two-factor repeated measures analysis of va nalysis between arms used Student's $t$-test. dit analys was used to assess ordinal data. Counts wo done by us g the $\chi^{2}$ test or Fisher's exact test. 0.05 was onside d statistically significant.

\section{Results}

There w significan serences in sex ratio, age, hypertension cla fication, ASA classification, BMI, $\mathrm{Hb}$, 0 anenal infor ation of the patients between the two rms $(P>0.05)$, as shown in Table 1 .

There we no significant differences in the HR or CVP v. es of $\mathrm{p}$ ents between the two arms. However, MAP values were statistically different between the two arms. 1. Thtients of the same arm, the values of MAP, HR, and CVP varied at different time points. There were cross-effects between arms and time points. Thus, it can be considered that the values and rates of change of MAP, HR, and CVP were different at different time points.

Compared with arm C, CVP values were higher at $\mathrm{T}_{4}$, $\mathrm{T}_{5}$, and $\mathrm{T}_{6}$, and $\mathrm{HR}$ values were higher at $\mathrm{T}_{3}, \mathrm{~T}_{4}, \mathrm{~T}_{5}$, and $\mathrm{T}_{6}$, in arm $\mathrm{G}$.

From the time point of view, MAP began to rise 1 hour after surgery and then began to decline to the levels from 30 minutes before surgery, continuing to decline until 12 hours after the operation. HR began to decline after surgery, then to rise 6 hours after surgery, reaching peak 12 hours after surgery. CVP began to rise after the start of surgery, rose to the highest value during surgery, and then began to decline 24 hours after the operation to the level from the beginning of the operation (Table 2).

Table I Basic information of the patients $(n=30)$

\begin{tabular}{|c|c|c|c|c|c|c|c|}
\hline Arm & $\begin{array}{l}\text { Sex } \\
(M / F)\end{array}$ & $\begin{array}{l}\text { Age } \\
\text { (years) }\end{array}$ & $\begin{array}{l}\text { Hypertension } \\
\text { classification (I/II/III) }\end{array}$ & $\begin{array}{l}\text { ASA } \\
\text { classification (II/III) }\end{array}$ & $\begin{array}{l}\text { BMI } \\
\left(\mathrm{kg} / \mathrm{m}^{2}\right)\end{array}$ & Hb (g/L) & $\begin{array}{l}\text { Operation } \\
\text { time (h) }\end{array}$ \\
\hline C & $29 / 11$ & $67.2 \pm 4.3$ & $7 / 14 / 9$ & $32 / 8$ & $24.1 \pm 3.3$ & $129.2 \pm 4.6$ & $4.3 \pm 1.2$ \\
\hline G & $31 / 9$ & $66.6 \pm 3.9$ & $6 / 14 / 10$ & $31 / 9$ & $24.4 \pm 4.2$ & $|3| .2 \pm 6.8$ & 4. $I \pm 1.3$ \\
\hline
\end{tabular}

Notes: Arm C received conventional infusion; arm G received goal-directed fluid therapy. Data are presented as number or mean \pm standard deviation. Abbreviations: ASA, American Society of Anesthesiologists; BMI, body mass index; Hb, hemoglobin. 
Table 2 Comparison of hemodynamics of patients between the two arms $(n=30)$

\begin{tabular}{|c|c|c|c|c|c|c|}
\hline \multirow{2}{*}{$\begin{array}{l}\text { Time } \\
\text { point }\end{array}$} & \multicolumn{2}{|c|}{ MAP $(\mathrm{mmHg})$} & \multicolumn{2}{|c|}{ HR (bpm) } & \multicolumn{2}{|c|}{ CVP $\left(\mathrm{cm} \mathrm{H} \mathrm{H}_{2} \mathrm{O}\right)$} \\
\hline & Arm C & Arm G & Arm C & Arm G & Arm C & Arm G \\
\hline $\mathrm{T}_{0}$ & $106.5 \pm 8.2$ & $106.9 \pm 6.1$ & $71.8 \pm 6.2$ & $75.5 \pm 10.5$ & $7.4 \pm 1.7$ & $7.0 \pm 1.7$ \\
\hline $\mathrm{T}_{1}$ & $107.5 \pm 7.9$ & $107.3 \pm 6.0$ & $68.8 \pm 5.4$ & $71.8 \pm 11.3$ & $8.3 \pm 1.9$ & $7.9 \pm 1.7$ \\
\hline $\mathrm{T}_{2}$ & $109.2 \pm 7.9$ & $110.8 \pm 6.5$ & $70.5 \pm 5.1$ & $70.3 \pm 8.4$ & $10.0 \pm 2.2$ & $9.3 \pm 1.8$ \\
\hline $\mathrm{T}_{3}$ & $100.2 \pm 7.5$ & $110.9 \pm 7.5^{*}$ & $71.8 \pm 5.0$ & $68.5 \pm 8.1$ & $11.1 \pm 1.7$ & $11.9 \pm 2.0$ \\
\hline $\mathrm{T}_{4}$ & $95.3 \pm 7.3$ & $109.6 \pm 6.8^{*}$ & $74.4 \pm 3.8$ & $70.0 \pm 8.0 *$ & $9.1 \pm 1.3$ & $10.9 \pm 1.6 *$ \\
\hline $\mathrm{T}_{5}$ & $93.9 \pm 6.1$ & $106.0 \pm 6.2^{*}$ & $75.5 \pm 4.0$ & $71.2 \pm 8.7^{*}$ & $7.8 \pm 1.2$ & $9.9 \pm 1.3 *$ \\
\hline $\mathrm{T}_{6}$ & $92.1 \pm 5.3$ & $106.1 \pm 4.8^{*}$ & $76.6 \pm 4.1$ & $71.9 \pm 8.6 *$ & $7.0 \pm 0.9$ & $8.6 \pm 1.4^{*}$ \\
\hline
\end{tabular}

Notes: Data are presented as mean \pm standard deviation. Arm $C$ received conventional infusion; arm $G$ received goal-directed fluid therapy. $T_{0}=30$ minutes before surgery; $T_{1}=$ at the beginning of surgery; $T_{2}=1$ hour after the initial surgery; $T_{3}=$ at the onset of surgery; $T_{4}=6$ hours after surgery; $T_{5}=12$ hours after surgery. ${ }^{*} P<0.05$ compared to arm $C$.

Abbreviations: CVP, central venous pressure; $\mathrm{HR}$, heart rate; MAP, mean arterial pressure.

The average volume of intravenous infusion in arm $\mathrm{G}$ $(2,732 \pm 488 \mathrm{~mL})$ was significantly lower than the value in $\operatorname{arm~C}(3,135 \pm 346 \mathrm{~mL})$. The amount of colloids was higher in $\operatorname{arm~G}(1,235 \pm 360 \mathrm{~mL})$ than in arm C $(760 \pm 280 \mathrm{~mL})$. There were no differences in intraoperative blood losses and urine outputs between the two arms. Arm G had a lower incidence of hypotensive events, thus patients in this arm had a smaller chance of requiring ephedrine (Table 3).

$\mathrm{ScvO}_{2}$ values between the two arms were statistically different. The difference in Lac value was significant betwe the two arms. At different time periods, the values of Scve and Lac varied and there were cross-effects between arms and time points.

Compared with arm $\mathrm{C}$, the averaged a tues of $\mathrm{cvO}_{2}$ were higher at $\mathrm{T}_{2}, \mathrm{~T}_{3}, \mathrm{~T}_{4}$, and $\mathrm{T}_{5}$ in arm $\mathrm{Th}$ ar alues an $\mathrm{T}_{3}, \mathrm{~T}_{4}$, and $\mathrm{T}_{5}$ were lower in arm $\mathrm{G}$. om the th point of view, $\mathrm{ScvO}_{2}$ was slightly elevate surgery, ho ained stable during surgery, starte to increase ter surgery, and then began to decline 12 ours after surgen, the preoperative levels. The va ss of $\mathrm{y}$ began to decrease during surgery to a minimum le cour afte urgery, then began to rise to the p po ive lo ap cemained stable thereafter (Table 4 and 5 )

Patients arn experlier onset of exhaust time than patients in $\mathrm{C}$. The averaged postoperative start time of defecation in arn was $3.6 \pm 1.4$ days, and was $4.3 \pm 1.9$ in arm C. The postoperative hospitalization time was shorter in arm G. The incidences of dsea, vomith an ypotension were lower in arm $\mathrm{G}$ th in arm There wue no statistical differences in del $\mathrm{am}$, a chmia, $r$ monary infection, pulmonary ede pulmonar, $\mathrm{mb}$ sm, wound infection/ dehiscence, irgurio intestinal fivula, mortality, and other complications between two arms (Table 6).

\section{Di cussion}

The bate abou ppropriate perioperative fluid treatment strategy going on for nearly half a century. Studies thy seported a number of inconsistent or even contradictory ints oviews. Although clinical trials or meta-analysis with arge sample sizes have been reported, researchers have failed prove that one method has overwhelming advantages over others. ${ }^{1-4}$ Recently, some researches proposed an ideal perioperative state of the loop. ${ }^{5-15}$ These literatures showed that for patients at high risk for death, perioperative fluid load or the combination with dobutamine could increase the $\mathrm{CI}$ and oxygen delivery index $\left(\mathrm{DO}_{2} \mathrm{I}\right)$ to extraordinary values $(\mathrm{CI}$ $\left.>4.5 \mathrm{~L} /\left[\mathrm{min} \cdot \mathrm{m}^{2}\right], \mathrm{DO}_{2} \mathrm{I}>650 \mathrm{~mL} /\left[\mathrm{min} \cdot \mathrm{m}^{2}\right]\right)$, significantly reducing patient hospital stay times or mortality. Subsequently, the GDFT term was introduced in many perioperative fluidmanagement studies. ${ }^{16}$

In recent years, more and more studies have started to reveal that the amount of perioperative transfusion is critical for maintaining the body's fluid balance. ${ }^{17}$ Studies showed that the colloid and crystalloid solutions were not exchangeable,

Table 3 Liquid intake and intraoperative administration of vasoactive drugs $(n=30)$

\begin{tabular}{llllll}
\hline Arm & $\begin{array}{l}\text { Intravenous infusion } \\
\text { volume }(\mathbf{m L})\end{array}$ & $\begin{array}{l}\text { Colloids } \\
(\mathbf{m L})\end{array}$ & $\begin{array}{l}\text { Blood } \\
\text { loss }(\mathbf{m L})\end{array}$ & $\begin{array}{l}\text { Urine output } \\
(\mathbf{m L} /[\mathbf{k g} \cdot \mathbf{h}])\end{array}$ & $\begin{array}{l}\text { Hypotensive } \\
\text { events }(\mathbf{n})\end{array}$ \\
\hline $\mathrm{C}$ & $3,135 \pm 346$ & $760 \pm 280$ & $473 \pm 156$ & $1.77 \pm 0.42$ & 9 \\
$\mathrm{G}$ & $2,732 \pm 488^{*}$ & $1,225 \pm 360^{*}$ & $482 \pm 168$ & $1.82 \pm 0.35$ & $2^{*}$ \\
\hline
\end{tabular}

Notes: Data are presented as mean \pm standard deviation. Arm $C$ received conventional infusion; arm $G$ received goal-directed fluid therapy. $* P<0.05$ compared to arm $C$. 
Table 4 Comparison of $\mathrm{ScvO}_{2}$ and $\mathrm{Lac}$ between the two arms $(\mathrm{n}=30)$

\begin{tabular}{llllll}
\hline \multirow{2}{*}{$\begin{array}{l}\text { Time } \\
\text { point }\end{array}$} & \multicolumn{2}{c}{$\mathrm{ScvO}_{2}(\%)$} & & \multicolumn{2}{c}{ Lac (mmol/L) } \\
\cline { 2 - 3 } \cline { 6 - 7 } & Arm C & Arm G & & Arm C & Arm G \\
\hline $\mathrm{T}_{0}$ & $71.4 \pm 6.2$ & $69.5 \pm 4.8$ & & $1.2 \pm 0.5$ & $1.1 \pm 0.3$ \\
$\mathrm{~T}_{1}$ & $72.8 \pm 5.6$ & $73.7 \pm 3.3$ & & $1.1 \pm 0.5$ & $1.1 \pm 0.3$ \\
$\mathrm{~T}_{2}$ & $71.4 \pm 5.4$ & $75.7 \pm 3.0^{*}$ & & $1.0 \pm 0.5$ & $1.0 \pm 0.3$ \\
$\mathrm{~T}_{3}$ & $73.5 \pm 5.2$ & $78.5 \pm 2.9^{*}$ & & $1.4 \pm 0.6$ & $0.9 \pm 0.2^{*}$ \\
$\mathrm{~T}_{4}$ & $71.6 \pm 4.8$ & $75.8 \pm 2.4^{*}$ & & $1.4 \pm 0.5$ & $1.0 \pm 0.2^{*}$ \\
$\mathrm{~T}_{5}$ & $70.8 \pm 4.8$ & $74.1 \pm 2.3^{*}$ & & $1.3 \pm 0.5$ & $1.0 \pm 0.2^{*}$ \\
$\mathrm{~T}_{6}$ & $70.9 \pm 4.2$ & $72.3 \pm 3.0$ & & $1.2 \pm 0.5$ & $1.1 \pm 0.2$ \\
\hline
\end{tabular}

Notes: Data are presented as mean \pm standard deviation. Arm $C$ received conventional infusion; arm $G$ received goal-directed fluid therapy. $T_{0}=30$ minutes before surgery; $T_{1}=$ at the beginning of surgery; $T_{2}=1$ hour after the initial surgery; $T_{3}=$ at the onset of surgery; $T_{4}=6$ hours after surgery; $T_{5}=12$ hours after surgery; $T_{6}=24$ hours after surgery. $* P<0.05$ compared to arm $C$.

Abbreviations: Lac, arterial blood lactate; $\mathrm{ScrO}_{2}$, central venous oxygen saturation.

even with an appropriate proportion such as $1: 3$ to $1: 5 \cdot{ }^{18-20}$ Using a crystal liquid supplement may retain most of the crystals in the blood vessels. However, it is not always ideal to use a colloidal solution, as surgeons need to consider various factors, such as drug indications, contraindications, and side effects. ${ }^{21-23}$

The results of our study showed that, although the patients in arm $\mathrm{G}$ received a significantly lower amount of intra infusion, they also received a much higher amount o olloids. Although patients in arm $\mathrm{C}$ received $\mathrm{n}$ there was no significant difference in the rount bleedit between the two arms. Compared wit rm C were higher at $\mathrm{T}_{4}, \mathrm{~T}_{5}$, and $\mathrm{T}_{6}$, and valu ower at $\mathrm{T}_{3}, \mathrm{~T}_{4}$, $\mathrm{T}_{5}$, and $\mathrm{T}_{6}$, in arm G. For pati in arm G, o probability of having postoperative hypotensio was lower, thus these patients were more lik to maintain re stable hemodynamics and good ti de perfy ion condition.

Studies have sh vn th GDFT intervention can not only lower the L? rels on in 24 b ars after surgery, but also reduce th meide e of in $1 .{ }^{24-31}$ In the present study, we discor ed that ancentrations in arm $\mathrm{G}$ were lower at $\mathrm{T}_{3}, \mathrm{~T}_{4}$, an as compared to the values in arm $\mathrm{C}(P<0.05)$,
Table 6 Comparison of postoperative complications between the two arms

\begin{tabular}{|c|c|c|}
\hline Indicators & $\begin{array}{l}\text { Arm C } \\
(n=30)\end{array}$ & $\begin{array}{l}\text { Arm G } \\
(n=30)\end{array}$ \\
\hline Onset of exhaust time (days) & $4.3 \pm 1.9$ & $3.6 \pm 1.4^{*}$ \\
\hline Postoperative hospitalization (days) & $12.2 \pm 2.4$ & $10.8 \pm 1.9 *$ \\
\hline Fever & 8 & 3 \\
\hline Nausea and vomiting & 9 & $2 *$ \\
\hline Delirium & 6 & 2 \\
\hline Hypotension & 8 & $I^{*}$ \\
\hline Arrhythmia & 5 & 1 \\
\hline Heart failure & 0 & 0 \\
\hline Oliguria & & 2 \\
\hline Pulmonary infection & & 2 \\
\hline Pulmonary edema & & 0 \\
\hline Pulmonary embolism & & 0 \\
\hline Wound infection/fract & & I \\
\hline Intestinal anastor & & I \\
\hline Death & 0 & 0 \\
\hline
\end{tabular}
th previous ylts. ${ }^{32}$ Studies on GDFT also showed nat $\mathrm{ScvO}_{2}$ was a reliable parameter to predict postoperative fect, with a uracies of $64.4 \%$ and $73 \% \cdot{ }^{33,34}$ In the present S. $\mathrm{V}$, the $\mathrm{y}$ aes of $\mathrm{ScvO}_{2}$ were higher at $\mathrm{T}_{2}, \mathrm{~T}_{3}, \mathrm{~T}_{4}$, and $\mathrm{T}_{5}$ in arniv, compared to arm C.

PFT achieves the goal of optimal oxygen delivery by maintaining or increasing cardiac output. Thus, the immune cells can be free of the risk of preoperative hypoperfusion or intestinal disorder-associated lymphoid tissue damage, thus promoting tissue healing and reducing infection rates. The traditional treatment programs often use a large number of crystal liquid, which can easily lead to tissue edema and postoperative low blood pressure. Postoperative side-effects may affect tissue healing and increase the incidence of complications such as severe pulmonary infections. In the present study, patients in arm $\mathrm{G}$ experienced shorter postoperative hospital stay, better postoperative recovery, and faster bowel movement recovery. Also, the incidences of postoperative complications

Table 5 Comparison of different indicators between Arm G and Arm C by ANOVA

\begin{tabular}{|c|c|c|c|c|c|c|}
\hline \multirow[t]{2}{*}{ Indicators } & \multicolumn{2}{|l|}{ Arm } & \multicolumn{2}{|l|}{ Time } & \multicolumn{2}{|c|}{ Arm $\times$ time } \\
\hline & $F$-value & $P$-value & $F$-value & $P$-value & $F$-value & $P$-value \\
\hline $\mathrm{MAP}(\mathrm{mmHg})$ & 23.98 & 0.00 & 81.50 & 0.00 & 54.35 & 0.00 \\
\hline HR (bpm) & 0.65 & 0.42 & 30.26 & 0.00 & 31.60 & 0.00 \\
\hline $\mathrm{CVP}\left(\mathrm{cm} \mathrm{H} \mathrm{H}_{2} \mathrm{O}\right)$ & 3.38 & 0.07 & 195.90 & 0.00 & 30.80 & 0.00 \\
\hline $\mathrm{ScvO}_{2}(\%)$ & 5.81 & 0.02 & 52.38 & 0.00 & 25.93 & 0.00 \\
\hline Lac (mmol/L) & 3.05 & 0.09 & 9.89 & 0.00 & 24.31 & 0.00 \\
\hline
\end{tabular}

Abbreviations: ANOVA, analysis of variance; $\mathrm{CVP}$, central venous pressure; $\mathrm{HR}$, heart rate; Lac, arterial blood lactate; MAP, mean arterial pressure; $\mathrm{ScvO}_{2}$, central venous oxygen saturation. 
such as nausea, vomiting, and hypotension were significantly lower in patients in arm $\mathrm{G}$ than in those in arm $\mathrm{C}$. Interestingly, there were no differences in the incidences of delirium, arrhythmia, pulmonary infection, pulmonary edema, pulmonary embolism, wound infection/dehiscence, oliguria, intestinal fistula, mortality, and other complications between the two arms. One possible explanation is that the type and amount of infusion may affect patients' prognosis, as $6 \%$ of hydroxyethyl starch solution was found to be more likely to maintain gastrointestinal microcirculation perfusion and oxygen tension than the crystal. ${ }^{35,36}$

\section{Study limitations}

There were some shortcomings in this study. The observation time of the patients participating in this study was short. In addition, the experiment was a small, single-center study. A larger-sample-size multicenter study would certainly help investigation of the potential of full-scale implementation of GDFT.

\section{Conclusion}

Overall, this study showed that GDFT application in elderly hypertensive patients can stabilize the perioperative hemodynamic situation, improve tissue perfusion, redu the incidence of postoperative complications, and shorte hospital stays.

\section{Acknowledgment}

This study was supported by the Joi Fujian Medical University, grant ny

\section{Disclosure}

The authors report no cor cts of interest in is work.

\section{References}

1. Pizon AF, Wolf Pos tum fo neurologic deficits: posterior leuko ephalo thy syn
163-166.

2. Chambers Cair molindness: two cases. Ann Emerg Med. 2004;43 3-246.

3. Long TR, Hein B Trown MJ, Rydberg CH, Wass CT. Posterior reversible encephalopathy trome during pregnancy: seizures in a previously healthy parturient. J Clin Anesth. 2007;19(2):145-148.

4. Singhal AB. Postpartum angiopathy with reversible posterior leukoencephalopathy. Arch Neurol. 2004;61(3):411-416.

5. Shoemaker WC, Appel PL, Kram HB, Waxman K, Lee TS. Prospective trial of supranormal values of survivors as therapeutic goals in high-risk surgical patients. Chest. 1988;94(6):1176-1186.

6. Hamilton-Davies C, Mythen MG, Salmon JB, Jacobson D, Shukla A, Webb AR. Comparison of commonly used clinical indicators of hypovolaemia with gastrointestinal tonometry. Intensive Care Med. 1997; 23(3):276-281.

7. Marik PE, Baram M, Vahid B. Does central venous pressure predict fluid responsiveness? A systematic review of the literature and the tale of seven mares. Chest. 2008;134(1):172-178.
8. Klatte T, Shariat SF, Remzi M. Systematic review and meta-analysis of perioperative and oncologic outcomes of laparoscopic cryoablation versus laparoscopic partial nephrectomy for the treatment of small renal tumors. J Urol. 2014;191(5):1209-1217.

9. Chua TC, Liauw W, Saxena A, et al. Evolution of locoregional treatment for peritoneal carcinomatosis: single-center experience of 308 procedures of cytoreductive surgery and perioperative intraperitoneal chemotherapy. Am J Surg. 2011;201(2):149-156.

10. Bienkowski P, Reindl R, Berry GK, Iakoub E, Harvey EJ. A new intramedullary nail device for the treatment of intertrochanteric hip fractures: Perioperative experience. J Trauma. 2006;61(6):1458-1462.

11. Nagy K, Muranyi M, Nadas G, Tapolcsanyi E, Vimlati L. [Perioperative treatment after esophagogastric surgery]. Magy Seb. 2001; 54(3):138-143. Hungarian.

12. Ming BSY. Chinese Hypertension Preventig Chinese Edition). People's Health Publishing House: Beijin eople's k blic of China; 2010.

13. Shafer SL, Stanski DR. Defining dep f anesthesia Iandb Exp Pharmacol. 2008;182:409-42

14. Bundgaard-Nielsen $\mathrm{M}, \mathrm{Sec}^{\prime} \mathrm{NH}, \mathrm{Kehlet} \mathrm{H}$. her s 'restrictive' perioperative fluid therar a critica' sessment ne evidence. Acta Anaesthesiol Scand. 2005, (7): 851.

15. Marik PE, Cavalla R, Vasu dirani A. P amic changes in arterial waveform deri variables and id re onsiveness in mechanically ventilated po9;37(9) $2042-26$ vitematic rev the literature. Crit Care Med.

16. Srinivan Taylor MH, gh PP, Yu TC, Soop M, Hill AG. Randomiz clinical trial of goal- $\mathrm{c}$ cted fluid therapy within an enhanced overy protocol for elective colectomy. Br J Surg. 2013;100:66-74.

17. shi GP. Intraop tive fluid restriction improves outcome after major tive gastroint inal surgery. Anesth Analg. 2005;101(2):601-605.

18. L vite J, Ner L, Cuvillon P, et al. Stroke volume optimization al othetic induction: An open randomized controlled trial mparing $0.9 \% \mathrm{NaCl}$ versus $6 \%$ hydroxyethyl starch 130/0.4. Ann Fr Anes reanim. 2013;32:e121-127.

Ni QY, Huang YX, Xu JY, Qiu HB. [Effects of different fluid resuscitations on mesenteric microcirculation in rabbits of acute hemorrhagic shock]. Zhonghua Yi Xue Za Zhi. 2013;93(9):693-697. Chinese.

. Li L, Zhang Y, Tan Y, Xu S. Colloid or crystalloid solution on maternal and neonatal hemodynamics for cesarean section: a meta-analysis of randomized controlled trials. J Obstet Gynaecol Res. 2013; 39:932-941.

21. Chappell D, Jacob M, Hofmann-Kiefer K, Conzen P, Rehm M. A rational approach to perioperative fluid management. Anesthesiology. 2008;109(4):723-740.

22. Bakker J, Coffernils M, Leon M, Gris P, Vincent JL. Blood lactate levels are superior to oxygen-derived variables in predicting outcome in human septic shock. Chest. 1991;99:956-962.

23. Munoz R, Laussen PC, Palacio G, Zienko L, Piercey G, Wessel DL. Changes in whole blood lactate levels during cardiopulmonary bypass for surgery for congenital cardiac disease: an early indicator of morbidity and mortality. J Thorac Cardiovasc Surg. 2000;119(1):155-162.

24. Lopes MR, Oliveira MA, Pereira VO, Lemos IP, Auler JO Jr, Michard F. Goal-directed fluid management based on pulse pressure variation monitoring during high-risk surgery: a pilot randomized controlled trial. Crit Care. 2007;11(5):R100.

25. Chytra I, Pradl R, Bosman R, Pelnár P, Kasal E, Zidková A. Esophageal Doppler-guided fluid management decreases blood lactate levels in multiple-trauma patients: a randomized controlled trial. Crit Care. 2007;11(1):R24.

26. Goodrich C. Continuous central venous oximetry monitoring. Crit Care Nurs Clin North Am. 2006;18(2):203-209.

27. Rivers EP, Ander DS, Powell D. Central venous oxygen saturation monitoring in the critically ill patient. Curr Opin Crit Care. 2001;7(3): 204-211.

28. Dueck MH, Klimek M, Appenrodt S, Weigand C, Boerner U. Trends but not individual values of central venous oxygen saturation agree with mixed venous oxygen saturation during varying hemodynamic conditions. Anesthesiology. 2005;103(2):249-257. 
29. Ladakis C, Myrianthefs P, Karabinis A, et al. Central venous and mixed venous oxygen saturation in critically ill patients. Respiration. 2001; 68(3):279-285.

30. Marx G, Reinhart K. Venous oximetry. Curr Opin Crit Care. 2006; 12(3):263-268.

31. Reinhart K, Bloos F. The value of venous oximetry. Curr Opin Crit Care. 2005;11(3):259-263.

32. Lindinger MI, Heigenhauser GJ, McKelvie RS, Jones NL. Role of nonworking muscle on blood metabolites and ions with intense intermittent exercise. Am J Physiol. 1990;258:R1486-1494.

33. Pearse R, Dawson D, Fawcett J, Wort S, Rhodes A, Grounds R. The relationship between central venous saturation and outcome following high-risk surgery. Crit Care. 2004;8(6):51.
34. Sax H, Uçkay I, Balmelli C, et al. Overall burden of healthcare-associated infections among surgical patients. Results of a national study. Ann Surg. 2011;253(2):365-370.

35. Kimberger O, Arnberger M, Brandt S, et al. Goal-directed colloid administration improves the microcirculation of healthy and perianastomotic colon. Anesthesiology. 2009;110(3):496-504.

36. Hiltebrand LB, Kimberger O, Arnberger M, Brandt S, Kurz A, Sigurdsson GH. Crystalloids versus colloids for goal-directed fluid therapy in major surgery. Crit Care. 2009;13(2):R40.



Drug Design, Development and Therapy

Dovepress

\section{Publish your work in this journal}

Drug Design, Development and Therapy is an international, peerreviewed open-access journal that spans the spectrum of drug design and development through to clinical applications. Clinical outcomes, patient safety, and programs for the development and effective, safe, and sustained use of medicines are a feature of the journal, which has also been accepted for indexing on PubMed Central. The manuscript management system is completely online and includes a very quick and fair peer-review system, which is all easy to use. Visit http://www.dovepress.com/testimonials.php to read real quotes from published authors.

Submit your manuscript here: http://www.dovepress.com/drug-design-development-and-therapy-journal 